\title{
Accounting
}

\section{Factors affecting business performance of manufacturing enterprises}

\author{
Le Anh Tuan ${ }^{a, b^{*}}$ and Nguyen Thi Huyen Tram
}

${ }^{a}$ Faculty of Accounting, Duy Tan University, Da Nang, 550000, Vietnam

${ }^{b}$ Institute of Research and Development, Duy Tan University, Da Nang, 550000, Vietnam

${ }^{c} H C M C$ University of Technology and Education, Ho Chi Minh city, Vietnam

\section{H R O N I C L E}

\section{Article history:}

Received: April 28, 2020

Received in revised format:

July 302020

Accepted: September 25, 2020

Available online:

September 25, 2020

Keywords:

Manufacturing enterprises

Business performance

Vietnam

\section{A B S T R A C T}

The study has surveyed 285 manufacturing enterprises in central Vietnam as a representative sample, through which the research has analyzed the current status of operation of manufacturing enterprises in Central Vietnam. The research results also pointed out 5 factors: (1) Labor; (2) Enterprise size; (3) Financial management capacity (4) Capital structure and (5) System of policies and legislation in descending order of affecting the performance of enterprises through regression model. Besides, the study has given specific policy suggestions through the current situation and research model to improve business performance for manufacturing enterprises in Central Vietnam in the future.

(C) 2021 by the authors; licensee Growing Science, Canada

\section{Introduction}

In recent years, along with the development and integration of Vietnam's economy, manufacturing enterprises play an increasingly important role, contributing significantly to the economic growth of the country. The efficiency of production and business of enterprises is the relationship between the results achieved in the production and business process with the costs spent to achieve that result. It reflects the level of input resources used to achieve the goals of the manufacturing enterprise. The results achieved and the cost and the level of use of the resources are directly affected by many different factors with different degrees and directly affects the efficiency, production and business of manufacturing enterprises. The scale of manufacturing enterprises is increasing, especially the group of manufacturing enterprises operating in the fields of industry, manufacturing and manufacturing products. According to the General Statistics Office in 2019, the service sector attracts the largest proportion of the entire business sector. As of December 31, 2018, this sector attracted VND 25.52 million for production and business, accounting for $65.6 \%$ of the capital of the entire business sector, up $19.7 \%$ over the same period. in 2017 ; industry and construction attracted 13.0 million billion VND, accounting for $33.4 \%$, up $14.7 \%$; the agriculture, forestry and fishery sector attracted 401.7 trillion VND, accounting for only $1.0 \%$, increasing by $20.9 \%$. It can be affirmed that the development of this industry group meets the practical requirement that our state is building, which is the development of a socialist-oriented market economy in parallel with the goal of industrialization - modernize the country.

\section{Background theory and premise studies}

\subsection{Business size}

The size of the enterprise can be understood as the total revenue, the total value of assets and capital, the number of workers and employees, large-scale enterprises will have favorable conditions in terms of prestige, brand name, and strength. Strong

* Corresponding author.

E-mail address: leanhtuan@duytan.edu.vn (L. A. Tuan) 
financial resources should have better access to capital (e.g. easier mobilization from investors, higher loan rates, lower interest rates). These businesses with financial strength, assets and management ability will easily exploit economies of scale to minimize input costs and increase output efficiency. The reasons for creating economies of scale:

- During the production and business process, there are always some inputs to maintain the operation of the enterprise, these factors do not depend on the production and business or not, those costs are called costs. is fixed and it does not vary with output. It starts at low levels of output and does not increase with increase in output.

When output increases, firms will gain economies of scale since these fixed costs can be divided by a larger number of units of output and thus reducing the average cost for unit of product. Large-scale businesses often need the advantage of new, modern machines, with high levels of production, the depreciation cost of machinery can be evenly resolved for a large number of products and with product technology. That can produce so many products that it reduces average costs. The large scale of output allows businesses to save transaction costs. When selling a larger volume, the cost of negotiating and communicating (via mail, phone, fax, etc.) does not increase proportionally compared to the case of selling a smaller volume.

Larger scale of output allows firms to take advantage of specialization. Labor and machines must be large enough to allow people to organize and use them in a specialized fashion.

They can be allocated and used exclusively for different stages of production through which their productivity can be increased. When the output is too small, none of the above will happen if the amount of input used is too low.

Some previous studies have found that enterprise size affects the operational efficiency of enterprises. The studies consider firm size such as assets, equity, number of employees, revenue. In some studies firm size has a positive impact on firm performance (Zeitun \& Tian, 2007; Margaritis \& Psillaki, 2007; Pouraghajan et al., 2012; Pervan \& Višić, 2012; Gleason et al., 2000).

\subsection{Policy and legal system}

\section{a. Macro policies of the Government}

Policy is the sum of the views, ideas, solutions and tools that the state uses to influence socio-economic entities to solve problems in order to achieve certain objectives.

The policy includes some contents such as:

+ Strategy: high, stable growth, income and sovereignty independence. Other policies: financial policy and monetary policy.

+ Context: a country includes resources such as natural resources, labor, capital, and technology of that country; subjects such as households, organizations, businesses, etc.; rules of the game such as law, social media, etc.; International organizations include international organizations, international associations.

+ Performance indicators: Economy includes inflation, unemployment, etc.; society includes income distribution, social issues, etc.; politics include government, democracy issues, etc.; Tariffs, balance of payments, etc.

In each specific period, the government will introduce macro policies to stabilize the macro-economy, creating a favorable framework for the development of businesses.

This factor is verified in the study of Zeitun and Tian (2007) and Schiantarelli and Sembenelli (1999). Accordingly, this factor affects the profitability and competitive environment of companies in Italy and the UK. These researchers have found a positive relationship between macro policy and firm performance.

State policies: In recent years, the Government has implemented many programs to support businesses in general and manufacturing enterprises in particular in accessing finance, business registration, and supporting the liberation and construction. building production premises, improving technology capacity, expanding markets, developing human resources, etc. These policies have contributed a great role to the development of manufacturing enterprises. In a study conducted by the International Financial Group (IFC, 2003) based on the responses of 45,000 enterprises in developing countries, it was found that the leading factors hindering the development of key businesses. is an unattractive investment environment such as high taxes, poor infrastructure or inadequate electricity supply, etc. All of the above negative effects are related to government policies. In addition, the business environment is seen as a factor affecting the development of production enterprises, including factors outside the enterprise, orientation and direct influence on management activities in the enterprise. Here, the Government plays a very important role in creating an attractive political and investment environment not only for production enterprises but also for the business system in general. In the current period, the business environment is increasingly difficult for manufacturing enterprises when faced with the negative impact of the financial crisis as a part of the production chain (contractors side) is heavily affected when large enterprises stop contracts to narrow the market for manufacturing enterprises. Therefore, in the view 
of Dess et al. (1997), the development of a manufacturing enterprise is influenced by its own business environment, besides others emphasized that the unstable business environment has negative consequences on the development of manufacturing enterprises.

Davidsson (1989) has argued that obstacles to tax policies, cumbersome legal systems or procedures can hinder the development of manufacturing firms. The legal system is one of the indispensable factors in business activities. It is a factor of the social superstructure, creating a common legal framework for normal business activities. In business, if grasping these factors, the guarantee of success will be great. Especially in international business where the political legal environment is much more diverse and complex, the study of the legal political environment is essential.

In Vietnam, manufacturing enterprises must always comply with the provisions of the Enterprise Law, legal regulations, state policies in socio-economic management, regulations on investment management, and approval. , inspect enterprises' activities, the regulations of the Provincial People's Committee and the management agencies directly under the Provincial People's Committee. Appropriate legal policies will facilitate and ensure strict, economical and efficient management, on the contrary, it will cause difficulties in the management and development of the enterprise system of competent state agencies. State policies or laws create fairness and create a healthy competitive environment between workers and workers, between individuals and organizations, and between businesses. Thus, it can be seen that the Government plays a major role in affecting the development of manufacturing enterprises, the obstacles coming from the Government may be the cause of disadvantages to the business activities of enterprises. In production, the role of the Government is not only to help production enterprises but also to create an attractive investment environment in order to attract investment enterprises.

\section{b. Local support policy}

Local supportive policies for manufacturing enterprises are influenced by general government policies. But in fact, when deployed, those policies are integrated with other action programs. This makes it difficult for manufacturing enterprises to access and benefit from government policies. Local governments at all levels still find it difficult to develop synchronous and effective policies for manufacturing enterprises. The settlement of investment and borrowing-related procedures by state management agencies is still slow with many shortcomings. Therefore, it has a great influence on the development of production enterprises. Although there are many industrial zones and industrial clusters, the problem of production premises is still an inherent problem for manufacturing enterprises. The main reason is related to financial difficulties or affordability, especially for newly established businesses. In addition to supportive policies for local manufacturing enterprises, the production business association also plays an important role for the development of manufacturing enterprises in general and manufacturing enterprises in particular. Thus, besides the support from the government, the local support policies have played a great role in supporting production enterprises.

\subsection{Capital structure}

Any business conducting production and business requires capital, enterprises must arrange reasonable funding for that capital demand. There are many sources of funding for the capital needs of businesses such as: equity, short-term loans, long-term bank loans, bond issues, etc. Financial structure affects profits for owners. Companies need to plan target capital structures.

Target capital structure is a harmonious combination of debt and equity in the company's total capital resources according to the target. Capital structure policymaking involves trade-offs between returns and risks.

\section{Modigliani \& Miller Theory}

Modigliani and Miller (1958) hypothesized and explored that the cost of capital increases or decreases when an enterprise increases or decreases its borrowing. To support this theory, Modilligani and Miller make a number of simplifying assumptions that are common in financial theory: they assume that capital markets are perfect; So, there will be no transaction costs, the loan rate is the same as the loan rate; Taxation is ignored and the risk is calculated entirely by uncertainty of cash flows. If the capital market is perfect, Modilligani and Miller argued: then firms with the same risk and the same expected annual return must have the same total value regardless of capital structure since the value of the firm must depend on the present value of its operations, not on the manner of funding. From here, it can be drawn that if all such firms have the same expected return and the same value, it must be the same at all levels of the ratio between debt capital and equity. Modilligani and Miller show that these effects are precisely balanced. Using debt gives owners a higher rate of return, but this higher return is exactly what they offset the increased risk from the ratio of debt to total capital. Modilligani and Miller (1963) provide a follow-up study with the elimination of the hypothesis of corporate income tax. According to Modilligani and Miller (1963), with corporate income tax, the use of debt will increase the value of the enterprise. Because interest expenses are reasonable expenses deducted when calculating corporate income tax, a part of the income of the enterprise using debt is transferred to investors. Therefore, the increase in enterprise value is thanks to the benefit from the tax shield. 
With the above hypothesis leading to using capital structure has no effect on enterprise value or in other words, enterprises cannot increase their values by changing capital structure.

\section{The theory of optimal capital structure}

The traditional concept of capital structure is that when a company starts to borrow, it increases liabilities, advantages outweigh disadvantages. The low cost of debt combined with the tax advantage will reduce the weighted average cost of capital as debt increases. However, as the ratio of debt to equity increases, it forces the owners to increase the required return of the shareholder (i.e. the cost of equity increases). At the same time, increasing debts can lead to higher production and business costs, thereby reducing the profits of the business. If the revenue increases as a result of production loans, but the profit falls sharply due to the increase in costs, the business performance of enterprises will decrease. Besides, when using debts, especially short-term debts, there is always a risk of bankruptcy when the solvency decreases to an alarming level. Thus, at a higher ratio of debt and equity, the weighted average cost of capital will increase.

Under this approach, enterprises can first lower the cost of capital through increasing the use of debt because the cost of debt is lower due to the tax savings. However, as the debt ratio increases, the risk also increases, owners have to increase the required return of the shareholder (i.e., the cost of equity increases), in time the benefit of tax savings. do not compensate for the increase in the average cost of capital, making the benefits of using debt disappear. At the same time, at a high level of debt and equity, the cost of debt also increases because the possibility of a business unable to repay its debt is higher (higher risk of bankruptcy).

Therefore, the optimal capital structure theory states that the capital structure has an impact on the average cost of capital and enterprise value, in other words, there is an optimal debt ratio, where the cost of capital is the smallest and the enterprise value is the largest. Thus, according to the Modigliani \& Miller theory and the optimal capital structure theory, we can see how the choice and use of capital will have an impact on the operational efficiency of enterprises. From previous studies by Zeitun and Tian (2007), Onaolapo and Kajola (2010), Margaritis and Psillaki (2007), Pouraghajan et al. (2012), Pervan and Višić (2012) and Gleason et al. (2000) we understand that the capital structure has a negative impact on the operational efficiency of enterprises.

\subsection{Financial management capacity}

Corporate financial management plays a great role in business operations of the business. In the process of operation, there often arise short-term and long-term capital needs for regular business activities of enterprises as well as development investment. The role of the financial administrator is to correctly determine the capital needs for business activities of the business in each period, actively choose the forms and methods of capital mobilization to ensure smooth and continuous operation of the business. with minimal funding costs. The efficiency of business activities depends heavily on the organization and use of capital. The manager must know to evaluate and select investment projects on the basis of analyzing the profitability and risk level of the projects from which the optimal investment project is selected. Timely mobilization of capital sources is very important for businesses to take advantage of business opportunities. To move to production and business action, every enterprise needs to have labor documents, labor objects and labor force and liquid assets mainly contribute to the role of workers. Working assets are short-term and frequently circulating assets, so it helps enterprises to turn around capital faster, reduce the cost of capital, and improve the efficiency of production and business. Working assets are cash, accounts receivable, inventory reserve, etc. In order to ensure that the business activities of the business are conducted continuously and effectively, the management and use of liquid assets have a great influence on the return and the general goal of the business. The inability of some companies to plan and control liquid assets is always the cause of bankruptcy. Therefore, the capacity of the administrator is how to keep money while ensuring daily business transactions, to meet the need for contingency in case of unforeseen fluctuations, how much materials and goods are needed. How much reserve is to promptly meet production and consumption without backlog or value reduction; or build a commercial credit policy to keep customers, increase the number of products.

Research by Siminica et al. (2012) shows the scope of investment capital, range of working capital needs, working capital turnover days, the ratio of working capital needs and the average collection period have positive impacts on the operational efficiency of the business. Besides, in the view of Olawale and Garwe (2010), management capacity is the knowledge, skills and capabilities of business owners that can help manufacturing enterprises operate more effectively. Others emphasized that the owner's managerial skills are essential for the survival and growth of the business.

\subsection{Labor}

Among the resources of enterprises, human resources are the most important and decisive for the growth and development of enterprises. Human resources with the leading factor of intelligence have an outstanding advantage in that it is not exhausted if they can be fostered, exploited and used properly, and other resources and human resources can only be effective when combined with human resources, effectively. Therefore, it can be said that the labor force and the quality of the workforce is a criterion to evaluate the strength of the enterprise. In the view of Hewitt and Wield (1992), if an enterprise has a well-trained, skilled and 
skilled workforce, it can create a higher business HQSX. In addition, human resource is one of the key factors for the success of manufacturing enterprises and especially Batra and Tan (2003) also show that the workforce is skilled. Good skills and training are more likely to learn and innovate. Along with that, Batra and Tan (2003) emphasized that low-skilled labor is the main obstacle to the development of manufacturing enterprises in developing countries.

\section{Research method}

Methods used in research are mixed methods, i.e. a combination of qualitative research methods and quantitative research methods. Firstly, in the qualitative research method, the author will use secondary data, which are dissertations, dissertations, studies, articles that are publicly available on the Internet or library of related universities to determine factors affecting the performance of business activities of enterprises combined with information related to the size and structure of operations of manufacturing enterprises in Central Vietnam. Statistics on the activities of the State are related to business activities of manufacturing enterprises. Primary data is collected by surveying the manufacturing enterprises operating in the central region of Vietnam. The author distributes random surveys to 200 business representatives (directors, deputy directors) operating in many different fields out of a total of more than 1,000 manufacturing enterprises operating in the Central region, Vietnam. This is aimed at improving the representativeness of the research sample, increasing the reliability of the surveyed subjects. Second, in the quantitative research method, the author will analyze and process the collected data that will be analyzed by SPSS software. The author conducts an analysis of the collected data to clarify the opinions of these businesses on the status of factors affecting the performance of business activities of manufacturing enterprises in Central Vietnam.

Research hypothesis

Based on the theory combined with the current status of business activities of manufacturing enterprises in Central Vietnam, the author focuses on researching a number of factors that affect the business performance of manufacturing enterprises. Exported in Central Vietnam.

Hypothesis $\mathrm{H}_{1}$ : Firm size has a positive impact on business performance of manufacturing enterprises.

Most studies by Zeitun and Tian (2007), Margaritis and Psillaki, M. (2007), Pouraghajan et al. (2012), Pervan and Višić (2012), Gleason et al. (2000) all found that the enterprise size has a positive and significant impact on the efficiency of the enterprise, i.e. the larger the scale, the more efficient the business is. In contrast, many other researchers such as Durand and Coeuderoy (2001), and Tzelepis and Skuras (2004) reported, on the contrary, that there is no significant effect between size and efficiency of firms.

Large-scale enterprises with financial strength, assets, capital, technology and management ability will easily exploit economies of scale to minimize input costs and increase output efficiency to reduce the product costs. In the study by Gleason et al. (2000), it is stated that the more businesses expand their revenue, the higher their business efficiency is.

Hypothesis $\mathrm{H}_{2}$ : The policy and legal system has a positive impact on the business performance of manufacturing enterprises.

This factor is verified in the study of Zeitun and Tian (2007), and Schiantarelli and Sembenelli (1999). Accordingly, this factor affects the profitability and competitive environment of companies in Italy and the UK. These researchers have found a positive relationship between macro policy and firm performance.

Here, the Government plays a very important role in creating an attractive political and investment environment not only for production enterprises but also for the business system in general. Therefore, in the view of Dess et al. (1997), the development of a manufacturing enterprise is influenced by its own business environment, emphasizing that the unstable business has negative consequences on the development of production enterprises.

Hypothesis $\mathrm{H}_{3}$ : Capital structure has a positive impact on business performance of manufacturing enterprises.

Like Zeitun and Tian (2007), another study by Schiantarelli and Sembenelli (1999) mentioned the effect of maturity debt structure on profitability of companies in Italy and the UK. They found a positive relationship between short-term debt to firm performance. It can be said that the choice of debt structure can affect both firm's performance. Therefore, in the capital structure factor, the author will consider the effect of term debt structure on the business performance of enterprises.

Hypothesis $\mathrm{H}_{4}$ : Financial management capacity has a positive impact on business performance of manufacturing enterprises.

Research by Siminica et al. (2012) shows the scope of invested capital, range of working capital needs, working capital turnover days, ratio of demand working capital demand, and the average collection period have a positive impact on the business performance of the business. According to Olawale and Garwe (2010) management capacity is the knowledge, skills and capabilities of business owners that can help manufacturing enterprises operate more efficiently. Pervan and Višić (2012) emphasized that the managerial skills of business owners are essential for the survival and growth of a business. In addition, 
others affirmed that management skills are the key factor for the development of an enterprise and if the owner lacks managerial skills, it is a major barrier for the development and it is a major factor on production and business activities failure.

Hypothesis $\mathrm{H}_{5}$ : High-quality labor has a positive impact on the business performance of manufacturing enterprises.

In the view of Hewitt and Wield (1992), if an enterprise has a well-trained and skilled workforce, it can create higher business efficiency. In addition, it is emphasized that human resource is one of the important factors for the success of manufacturing enterprises (Batra \& Tan, 2003). It also shows that a well-trained and skilled workforce is more likely to learn and innovate. Along with that, Batra and Tan (2003) emphasized that low-skilled labor is the main obstacle for the development of manufacturing enterprises in developing countries.

\section{Table 1}

Synthesis of research hypotheses

\begin{tabular}{|c|c|c|c|}
\hline Factor & Encode & Hypothesis & Related studies \\
\hline Firm size & QMDN & + & $\begin{array}{l}\text { Zeitun \& Tian (2007), Margaritis and Psillaki (2007), Pouraghajan et al. (2012), Maja } \\
\text { Pervan \& Josipa Višić (2012), Gleason et al. (2000) }\end{array}$ \\
\hline The policy and legal system & CSPL & + & Zeitun \& Tian (2007), Schiantarelli \& Sembenelli (1999), Lumpkin \& Dess (1996), \\
\hline Capital structure & CCVO & + & $\begin{array}{l}\text { Zeitun \& Tian (2007), Margaritis \& Psillaki (2007), Pouraghajan \& Malekian (2012), } \\
\text { Pervan \& Višić (2012), Gleason et al. (2000) }\end{array}$ \\
\hline Financial management capacity & NLQT & + & Siminica et al. (2011), Olawale \& Garwe (2010) \\
\hline Quality of labor & CLLĐ & + & Hewitt \& Wield (1992), Batra \& Tan (2003), Lee (2001) \\
\hline Business performance efficiency & HQHĐ & & $\begin{array}{l}\text { Zeitun \& Tian (2007), Margaritis \& Psillaki (2007), Pouraghajan \& Malekian (2012), } \\
\text { Pervan \& Višić (2012), Gleason et al. (2000) }\end{array}$ \\
\hline
\end{tabular}

\section{Research models}

Based on the above research hypotheses, the author proposes a model to test hypotheses on factors affecting the efficiency of business activities of manufacturing enterprises in Central Vietnam, as follows:

Research models:

$\mathrm{HQH}_{\mathrm{i}, \mathrm{t}}=\beta_{0}+\beta_{1} \mathrm{QMDN}_{\mathrm{i}, \mathrm{t}}+\beta_{2} \mathrm{CSPL}_{\mathrm{i}, \mathrm{t}}+\beta_{3} \mathrm{CCVO}_{\mathrm{i}, \mathrm{t}}+\beta_{4} \mathrm{NLQT}_{\mathrm{i}, \mathrm{t}}+\beta_{5} \mathrm{CLL}_{\mathrm{i}, \mathrm{t}}$

Inside:

Operational efficiency: The dependent variable, the operational efficiency of manufacturing enterprises in the central region, Vietnam.

Independent variables:

- QMDN: Business size.

The size of the enterprise is understood as the level of revenue, asset level, capital source, number of workers. These businesses with financial strength, assets and management ability will easily exploit economies of scale to minimize input costs and increase output efficiency.

- CSPL: Legal policy

Including the macro policies of the Government in general and the locality in the Central region, Vietnam in particular in order to mobilize socio-economic actors to help create a specific development mechanism for manufacturing enterprises in the locality.

- CCVO: Capital structure

Capital structure including the structure of assets, the proportion of loans and liabilities to equity ensuring balance and safety will help manufacturing enterprises in the province improve their efficiency and business activities

- NLQT: Financial management capacity.

Referring to the role of a financial manager, it is necessary to have knowledge and skills to ensure a stable financial performance of the manufacturing enterprise, develop clear and relevant short-term financial strategies as well as long-term financial strategy plans.

- Labor force: Quality of labor 
L. A. Tuan and N. T. H. Tram /Accounting 7 (2021)

Labor quality plays a very important role in achieving high efficiency of manufacturing enterprises. It is necessary to have the quality of the workforce with guaranteed qualifications, techniques, a long-term commitment to the business.

\section{Result}

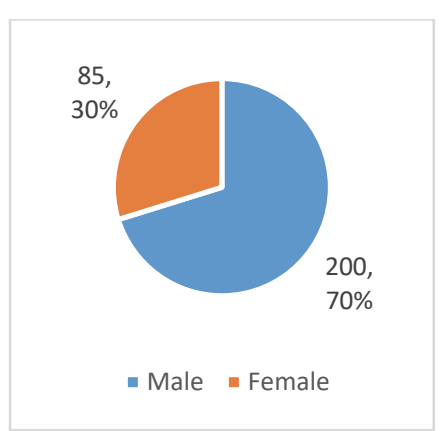

Gender

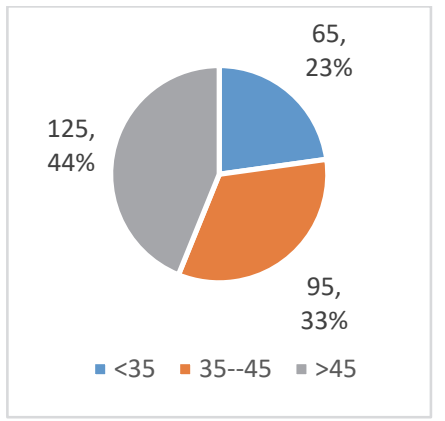

Age

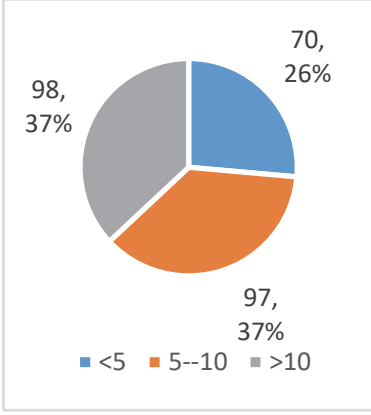

Work experience

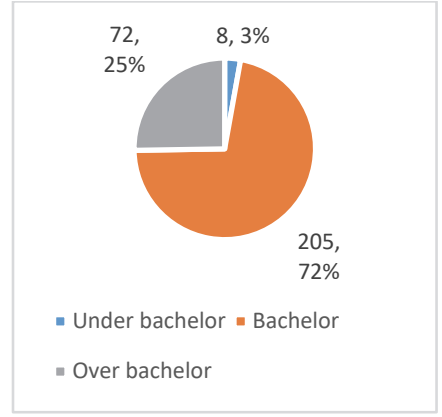

Educational background

Fig. 1. Personal characteristics of the participants

Fig. 1 demonstrates the summary of the personal characteristics of the participants in our survey.

\section{Table 2}

Results of reliability analysis and factor analysis

\begin{tabular}{|c|c|c|c|c|}
\hline No & Group variables & & Number of observation variables & Cronbach's Alpha \\
\hline 1 & Firm size & QMDN & 4 & 0.876 \\
\hline 2 & The policy and legal system & CSPL & 8 & 0.890 \\
\hline 3 & Capital structure & CCVO & 5 & 0.778 \\
\hline 4 & Financial management capacity & NLQT & 5 & 0.840 \\
\hline 5 & Quality of labor & CLLĐ & 5 & 0.902 \\
\hline 6 & Business performance efficiency & HQHĐ & 4 & 0.919 \\
\hline
\end{tabular}

Through the analysis results of Cronbach's Alpha coefficient, we can see that 5 scale components of the assessment of factors affecting the performance of production and business activities of manufacturing enterprises and dependent factors have reliability greater than 0.00 which can be trusted to use (See Table 3).

\section{Table 3}

Rotation matrix of independent factors

\begin{tabular}{|c|c|c|c|c|c|}
\hline & \multicolumn{5}{|c|}{ Component } \\
\hline & 1 & 2 & 3 & 4 & 5 \\
\hline$\overline{\mathrm{CCVO} 4}$ & 0.899 & & & & \\
\hline CCVO3 & 0.883 & & & & \\
\hline $\mathrm{CCVO} 2$ & 0.846 & & & & \\
\hline CCVO1 & 0.844 & & & & \\
\hline NLQT1 & & 0.918 & & & \\
\hline NLQT4 & & 0.867 & & & \\
\hline NLQT2 & & 0.857 & & & \\
\hline NLQT3 & & 0.831 & & & \\
\hline CLLD4 & & & 0.909 & & \\
\hline CLLD2 & & & 0.897 & & \\
\hline CLLD1 & & & 0.852 & & \\
\hline CLLD3 & & & 0.782 & & \\
\hline QMDN4 & & & & 0.857 & \\
\hline QMDN1 & & & & 0.844 & \\
\hline QMDN3 & & & & 0.835 & \\
\hline QMDN2 & & & & 0.822 & \\
\hline CSPL4 & & & & & 0.830 \\
\hline CSPL1 & & & & & 0.816 \\
\hline CSPL2 & & & & & 0.667 \\
\hline CSPL3 & & & & & 0.623 \\
\hline CSPL8 & & & & & 0.618 \\
\hline CSPL6 & & & & & 0.609 \\
\hline
\end{tabular}

Extraction Method: Principal Component Analysis.

Rotation Method: Varimax with Kaiser Normalization.

a. Rotation converged in 6 iterations. 
186

This shows that the scale is built with statistical significance and achieves the necessary reliability coefficient, and is further included in the factor analysis of discovery EFA. Based on the matrix of factor rotation when running EFA, it was found that the remaining 22 variables were extracted into 5 factors and no variable was eliminated. Thus, after testing the reliability of Cronbach's Alpha and analyzing the discovery factor EFA, the initial 22 observed variables were not eliminated. 22 observed variables are grouped into 5 factors and these 5 factors have no change in comparison with the original proposed research model but change in order of these 5 factors as follows,

- Factor 1: Capital structure, measured by variables CCVO4, CCVO3, CCVO2, CCVO1.

- Factor 2: Financial governance capacity, measured by NLQT1. NLQT4, NLQT2, NLQT3.

- Factor 3: Labor quality, measured by variables CLLD4, CLLD2, CLLD1, CLLD3.

- Factor 4: Firm size, measured by variables QMDN4, QMDN1, QMDN3, QMDN2.

- Factor 5: Legal basis, measured by variables CSPL4, CSPL1, CSPL2, CSPL3, CSPL8, CSPL6.

\section{Factor analysis EFA}

After checking the reliability of the scale with Cronbach's Alpha coefficients and removing variables that do not guarantee the reliability, we will continue to analyze the discovery factor EFA. This is the technique used to extract observed variables into one or more factors. The exploratory factor analysis method EFA is widely used in the research to preliminary assess the scales.

\section{The EFA analysis for the independent variable}

First, to check if the independent factors are suitable for inclusion in the exploratory factor analysis, we conduct Bartlett's test and KMO's coefficient.

\section{Table 4}

KMO coefficients and Bartlett's tests of independent factors KMO coefficient

Bartlett's test

\begin{tabular}{ll} 
& 0,809 \\
Approx. Chi-Square & 3854.573 \\
Df & 276 \\
Sig. & 0.000 \\
\hline
\end{tabular}

Based on Table 4, KMO value is $0.809>0.5$ and Sig value of Bartlett's test is $0.000<0.05$, showing that the variables are correlated with each other, so the model is suitable for inclusion in exploratory factor analysis. The extraction method in factor analysis requires that the extracted Eigenvalue values must be greater than 1 to be retained in the extracted 5-factor analysis model with Eigenvalue value greater than 1 and the stop when extracting the factors. At factor 5, there is an Eigenvalue of $1.208>1$. The total variance extracted of 5 factors is equal to $71.932 \%>50 \%$, which shows that the ability to use these 5 components explains $71.932 \%$ of the variability of the variables. observe.

\section{EFA analysis for the dependent variable}

The result of factor analysis to discover EFA with KMO is $0.810>0.5$ and Bartlett's test has sig equal to $0.000<0.05$, so we can confirm that the data is suitable for factor analysis (See Table 5).

\section{Table 5}

KMO coefficient and Bartlett's test of the dependent variable

KMO coefficient

Bartlett's test

\begin{tabular}{ll|} 
Approx. Chi-Square & $\mathbf{0 , 8 9 7}$ \\
df & 1216.577 \\
Sig. & 10 \\
\hline
\end{tabular}

Table 6

Regression coefficient

\begin{tabular}{|c|c|c|c|c|c|c|c|c|c|}
\hline \multirow{2}{*}{\multicolumn{2}{|c|}{ Model }} & \multicolumn{2}{|c|}{ Unstandardized } & \multirow{2}{*}{$\begin{array}{c}\text { Standardized } \\
\text { Beta } \\
\end{array}$} & & \multirow[b]{2}{*}{$\mathrm{T}$} & \multirow[b]{2}{*}{ Sig. } & \multicolumn{2}{|c|}{ Collinearity Statistics } \\
\hline & & B & Std. Error & & & & & Tolerance & VIF \\
\hline 1 & (Constant) & $-1.819 \mathrm{E}-16$ & .043 & & & .000 & 1.000 & & \\
\hline & F_HQHD & .320 & .043 & & .320 & 7.374 & .000 & 1.000 & 1.000 \\
\hline & F_CCVO & .211 & .043 & & .211 & 4.870 & .000 & 1.000 & 1.000 \\
\hline & F_NLQT & .216 & .043 & & .216 & 4.989 & .000 & 1.000 & 1.000 \\
\hline & F_QMDN & .288 & .043 & & .288 & 6.634 & .000 & 1.000 & 1.000 \\
\hline & F_CLLD & .432 & .043 & & .432 & 9.955 & .000 & 1.000 & 1.000 \\
\hline & F_CSPL & .117 & .043 & & .117 & 2.698 & .007 & 1.000 & 1.000 \\
\hline
\end{tabular}

a. Dependent Variable: F_HQHD 
Analysis has extracted from 5 scales of efficiency of production and business activities into a major factor with Eigenvalue of 3,975 and total variance extracted is $79,501 \%>50 \%$. After extracting factors from discovery factor analysis, we conduct regression analysis to determine the factors affecting the efficiency of production and business activities (Table 6). Regression analysis will be performed with 5 independent factors: capital structure, labor, financial management capacity, business size, policy and legal system. The value of each factor used to run the regression is the average value of the observed variables of that factor.

Table 7

Test of cointegration phenomenon

\begin{tabular}{llllll}
\hline Model & R & R Square & Adjusted R Square & Std. Error of the Estimate & Durbin-Watson \\
\hline 1 & $.651^{\mathrm{a}}$ & .577 & .566 & .73107051 & 1.615 \\
\hline
\end{tabular}

The standardized regression would be:

$\mathrm{HQHD}=0.211 \mathrm{CCVO}+0.216 \mathrm{NLQT}+0.288 \mathrm{QMDN}+0.432 \mathrm{CLLD}+0.117 \mathrm{CSPL}$

Test the model's hypotheses

After testing the existence of the model, we continue to test the model's hypotheses. It is to test the impact and influence of the independent factors on the dependent factors by the system of respective hypotheses of each factor.

To test the existence of the factors we base on the value of $\mathrm{Sig}$ of t-test. If $\mathrm{Sig}<0.05$, then reject hypothesis $\mathrm{H}_{0}$, accept hypothesis $\mathrm{H}_{1}$. In other words, the regression coefficients are statistically significant and have an impact on the performance of production and business activities.

Based on the results:

The factor CLLD has a value of $\mathrm{Sig}=0.000<0.05$, so H0 is rejected, meaning that labor affects the efficiency of production and business activities.

The value of IR factor is $\mathrm{Sig}=0.000<0.05$, so H0 is rejected, meaning that the financial management capacity affects the efficiency of production and business activities.

The factor of CCVO has a value of $\mathrm{Sig}=0.000<0.05$, so $\mathrm{H} 0$ is rejected, meaning that the capital structure affects the efficiency of production and business activities.

The QMDN factor has a value of $\mathrm{Sig}=0.000<0.05$, so $\mathrm{H} 0$ is rejected, meaning that the size of the business affects the efficiency of production and business activities.

The CSPL factor has a value of Sig $=0.007<0.05$, so H0 should be rejected, meaning that the system of legal regulations and policies affects the efficiency of production and business activities.

\section{Conclusion and Suggestions}

\subsection{Business size}

The larger the size of the enterprise, the higher the operational efficiency. This result is consistent with the theory and research results of Zeitun and Tian (2007), Margaritis and Psillaki (2007), Pouraghajan et al. (2012), Pervan and Višić (2012) and Gleason et al. (2000). Enterprises with large scale of operation can promote the efficiency of using assets, increase the company's profits, leading to a significant increase in the rate of profit on the total assets. According to the analysis results, the larger the scale, the more efficient the enterprises operate, indicating that enterprises need to increase the scale of their businesses to suit the actual situation in the locality and their capacity. of the enterprise. First of all, in the spirit of converting the type of company into a limited liability company, it will help businesses change their size and business methods, because in these types of businesses can mobilize share capital from shareholders. or business members to easily change the size of the business. On the other hand, with the above type of business, it is easy to build prestige as well as brand name with credit institutions combined with awards to improve the social relationships and qualifications of business owners, from which it can be mobilize funding from credit institutions to help businesses expand production and business scale.

\subsection{Legal policy system}

The state's support policy affects the business performance of enterprises and that this relationship is positive, meaning that the more support businesses receive from the state, the more effective their business activities are. In business activities, it is 
impossible to avoid the influence of state policies such as economic management policy, tax policy, investment policy, etc. The above-mentioned policies of the state often directly or indirectly affect each enterprise. Therefore, the policies of the state business support for enterprises will help enterprises invest in expanding production, feel secure in implementing business activities and create conditions for enterprises to improve the efficiency of production and business. Therefore, supportive policies of the state have a positive correlation with the efficiency of business activities of enterprises.

\subsection{Capital structure}

High growth rate has a positive impact on operating efficiency. Enterprises increasingly focus on expanding investment to achieve effective business activities and growing. This result is consistent with the theory and research results of Batra and Tan (2003). Research results show that the investment in fixed assets does not affect the efficiency of business activities. This result is not consistent with the theory and research results of Zeitun and Tian (2007) and Onaolapo and Kajola (2010). This is on contrary to the hypothesis that may stem from the ineffective investment in fixed assets, enterprises choosing technology, machinery and equipment that are not suitable for construction activities. Enterprises have not used assets effectively: Fixed assets have not been used at full capacity. Or with many different types of projects, when businesses buy themselves, the cost of hiring machines to perform construction is lower and effective. In addition to buying machines, for maintenance, maintenance and management of the machine, causing capital backlog while waiting for the machine to work. Production enterprises need to strictly control operating costs, carefully manage revenue and expenditure stages in enterprises such as saving unreasonable expenses, trying to save money to lower product costs to improve competitiveness. The market brings higher profits to help businesses operate efficiently and develop well and planning to use capital invested in projects reasonably for the process of scaling production and business and re-production. They build a strict financial management system such as using modern software to manage revenue and expenditure and profit of enterprises to ensure financial resources to avoid losses and easily check the financial situation of enterprises while necessary. Therefore, businesses try to perfect this system.

\subsection{Financial management capacity}

Operational efficiency is affected by debt recovery and debt policy of enterprises. The higher the ability to convert receivables into cash, the more operational efficiency will increase. Enterprises do not manage receivables well from customers, investors continue to prolong debt. When constructing projects without recovering receivables, enterprises will have to seek external support capital and be under pressure of interest. The shortage of capital to invest in production reduces the efficiency of business activities. Production enterprises develop effectively, the qualifications of the business owners are now less important, the more highly qualified the business owner, the better the business owner's diplomacy and manner, the better the Establishing a relationship, in addition, the high level of business owners helps businesses get more modern business methods, better business strategies and policies, so business owners need to foster or equip. With more knowledge, to achieve this, business owners need to take advantage of the opportunity to rely on the business development and training project for local enterprises to be the leader of the advisory scheme for the Provincial People's Committee. In addition, business owners need to learn more by themselves thanks to the advice of experts to provide them with more knowledge and higher qualifications to help businesses achieve better efficiency.

\subsection{Labor}

In the team of managers, especially senior managers such as directors of enterprises with their qualities and talents, will have the most important role, decisive influence on the success of a DN. The results and operational efficiency of corporate governance all depend greatly on the professional qualifications of the directors of enterprises. A well-educated director will conduct the business more effectively and methodically, as well as build the corporate governance structure of the enterprise and define the functions, duties and powers of each functional department. In addition, the director of a business with a good education will help businesses absorb and apply new better management methods and technologies. Therefore, the higher the level of director, the better the business performance of the business.

Enterprises need to have appropriate recruitment policies, training and appropriate assignment of jobs. Besides, it is necessary to have policies to retain good people such as creating a good working environment to help them promote their forte, good salary policy and reasonable reward regime.

Currently, the People's Committees of provinces and cities need to have a project to train human resources to help production enterprises in their area manage, seize this opportunity businesses try to replace and rotate weak managers in Instead the parts are of higher qualifications. But enterprises must have solutions and on-site training roadmap for staff to serve the operation of enterprises to ensure autonomy.

Enterprises need to perfect the system of policies on welfare regimes for employees such as reasonable salaries, rewards, care for employees' lives, encourage employees, create confidence and long-term efforts. long term with DN. 
Building a good corporate culture to ensure a good working environment, favorable cooperation and solidarity among business members to avoid loss of internal solidarity.

Limitations of topic

Based on the research results of the topic, it is found that the topic has some limitations and the next research direction to be able to complete the research topic as follows:

Due to the limited time, the relative number of observations has only 285 observations, so it is not possible to accurately assess the factors that can affect the business performance of manufacturing enterprises throughout Central, Vietnam.

Research has not yet evaluated all factors (macro, micro) affecting the efficiency of business activities of manufacturing enterprises in the area.

In addition, the topic is implemented at a time when manufacturing enterprises still face many difficulties in business activities and is gradually narrowing in number and field of activities after the Covid-19 epidemic. In addition, in the general context of the whole economy facing many difficulties, it also significantly affects the business activities of manufacturing enterprises. These issues are currently of special concern to the whole society such as tax policies, supportive policies for manufacturing enterprises so it is difficult to access enterprises to collect data.

\section{Further research directions}

In order to make the research results on business performance efficiency of manufacturing enterprises in the Central region in particular and Vietnam in general more accurate, the following researches follow the following directions:

Conducting research with a larger sample size to be able to survey and evaluate the efficiency of business activities of manufacturing enterprises in the Central to estimate the research model more accurately,

Expand the surveyed area to manufacturing enterprises in many central provinces, thereby assessing the efficiency of business activities of manufacturing enterprises will be more accurate,

Adding new variables (macro, micro) to the research model to be able to identify and evaluate more accurately the factors that can affect the business performance of manufacturing enterprises in Central Vietnam.

\section{References}

Batra, G., \& Tan, H. (2003). SME technical efficiency and its correlates: Cross-national evidence and policy implications. World Bank Institute Working Paper, 9.

Davidsson, P. (1989). Entrepreneurship_and after? A study of growth willingness in small firms. Journal of Business Venturing, 4(3), 211-226.

Dess, G. G., Lumpkin, G. T., \& Covin, J. G. (1997). Entrepreneurial strategy making and firm performance: Tests of contingency and configurational models. Strategic Management Journal, 18(9), 677-695.

Gleason, K. C., Mathur, L. K., \& Mathur, I. (2000). The interrelationship between culture, capital structure, and performance: evidence from European retailers. Journal of Business Research, 50(2), 185-191.

Hewitt, T., \& Wield, D. (1997). Networks in Tanzanian industrialisation. Science and Public Policy, $24(6), 395-404$.

Hoàng Quốc Mậu (2017), Nghiên cưu các nhân tố ảnh huởng đến hiệu quả kinh doanh của các doanh nghiệp vật liệu nổ công nghiệp ở Việt Nam, Luận án tiến sĩ, Đại học Kinh tế Quốc dân. (Research on factors affecting business efficiency of industrial explosives enterprises in Vietnam, $\mathrm{PhD}$ thesis, National Economics University.)

Hồ Tiến Dũng (2007), Quản trị sản xuất(Production Management), NXB Thống kê.

Margaritis, D., \& Psillaki, M. (2007). Capital structure and firm efficiency. Journal of Business Finance \& Accounting, 34(910), 1447-1469.

Modigliani, F., \& Miller, M. H. (1958). The cost of capital, corporation finance and the theory of investment. The American economic review, 48(3), 261-297.

Muritala, T. A. (2012). An empirical analysis of capital structure on firms' performance in Nigeria. International Journal of Advances in Management and Economics, 1(5), 116-124.

Nagy, N. (2009). Determinants of Profitability: What Factors play a role when assessing a firm's return on assets. The University of Akron, Department of Economics.

Olawale, F., \& Garwe, D. (2010). Obstacles to the growth of new SMEs in South Africa: A principal component analysis approach. African Journal of Business Management, 4(5), 729-738.

Pervan, M., \& Višić, J. (2012). Influence of firm size on its business success. Croatian Operational Research Review, 3(1), 213223. 
Pouraghajan, A., Malekian, E., Emamgholipour, M., Lotfollahpour, V., \& Bagheri, M. M. (2012). The relationship between capital structure and firm performance evaluation measures: Evidence from the Tehran Stock Exchange. International Journal of Business and Commerce, 1(9), 166-181.

Schiantarelli, F., \& Sembenelli, A. (1999). The maturity structure of debt: Determinants and effects on firms' performance? Evidence from the United Kingdom and Italy. The World Bank.

Siminica, M., Circiumaru, D., \& Simion, D. (2012). The correlation between the return on assets and the measures of financial balance for Romanian companies. International journal of mathematical models and methods in applied sciences, 6(2), 232253.

Tzelepis, D., \& Skuras, D. (2004). The effects of regional capital subsidies on firm performance: an empirical study. Journal of Small Business and Enterprise Development.

Zeitun, R., \& Tian, G. G. (2007). Capital structure and firm performance: evidence from Jordan. Australia Accounting Business and Finance Journal, 1(4), 148-168.

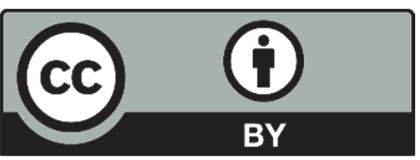

(C) 2020 by the authors; licensee Growing Science, Canada. This is an open access article distributed under the terms and conditions of the Creative Commons Attribution (CC-BY) license (http://creativecommons.org/licenses/by/4.0/). 